\title{
The Employee Is Always Right: Employee Satisfaction and Corporate Performance in Brazil
}

\author{
O Funcionário Sempre Tem Razão: Satisfação dos Empregados e Desempenho no Brasil
}

\begin{tabular}{|c|c|c|c|c|c|c|c|c|}
\hline & 1 & 2 & 3 & 4 & 5 & 6 & 7 & 8 \\
\hline 1st round & 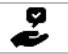 & $\otimes$ & $\stackrel{9}{2}$ & $\otimes$ & & & & \\
\hline 2nd round & 8 & & & & & & & \\
\hline
\end{tabular}




\title{
Resumo
}

Este artigo analisa a relação entre a satisfação dos empregados e o desempenho das empresas com base em uma ampla base de dados composta por 114.004 avaliações anônimas relativas às 1.000 maiores empresas brasileiras de 2013 a 2017 postadas no website Glassdoor. Como principal resultado, observa-se que a satisfação dos empregados é positivamente associada ao desempenho das empresas e esse resultado é economicamente relevante. Das quatro dimensões principais de bem-estar dos empegados, a relação com o desempenho é mais forte para a dimensão cultura, seguida de oportunidades de carreira. Por outro lado, a dimensão relativa à remuneração se mostrou a menos associada ao desempenho. Analisados em conjunto, os resultados corroboram a ideia de que os motivadores intrínsecos são mais importantes para um desempenho superior do que os motivadores extrínsecos caracterizados pela abordagem tradicional da cenoura e do chicote para a gestão das empresas. Adicionalmente, observa-se que a influência da satisfação dos empregados tende a ser assimétrica, no sentido de que é mais provável que as empresas caracterizadas por um baixo nível de satisfação dos funcionários provavelmente exibam um desempenho inferior do que aquelas com elevada satisfação apresentem um desempenho destacado. No conhecimento dos autores, este é o primeiro trabalho a documentar uma relação assimétrica entre desempenho das empresas e satisfação dos empregados, assim como o primeiro a investigar este tema em um mercado emergente com base em avaliações online anônimas.

Palavras-chave: satisfação dos empregados, capital humano, cultura organizacional, ativos intangíveis, desempenho corporativo.

\begin{abstract}
I investigate the effect of employee satisfaction on corporate performance based on an extensive dataset of 114,004 online reviews of Brazil's 1,000 largest listed and unlisted firms from 2013 to 2018 posted at a local subsidiary of Glassdoor. I find that overall employee satisfaction is positively associated with firm performance and that this relationship is likely to be economically relevant. Among the four dimensions of employee well-being, the link with performance is most evident for the dimension on culture, followed by career opportunities. On the other hand, the dimension on compensation and benefits was the least connected with firm performance. Taken together, these results support the view that intrinsic motivators are more relevant for superior performance than extrinsic ones popularized by the carrot and stick approach to management. I also find that the influence of employee satisfaction on performance is likely to be asymmetrical, in the sense that workplaces characterized by low satisfaction among workers are more likely to lead to poor performance than best-in-class companies are likely to produce superior performance. To my knowledge, this is the first paper to document an asymmetrical link between firm value and employee satisfaction, as well the first one to investigate this issue in an emerging economy using online reviews.
\end{abstract}

Keywords: employee satisfaction, human capital, corporate culture, intangible assets, online reviews, firm performance.

JEL Code: G3, N26, O15. 


\section{Introduction}

How important is employee satisfaction for the performance of firms? Although this is a critical issue for the way companies are managed and governed, empirical research in corporate finance to investigate this question has been surprisingly scarce so far. In addition to the classical view in economics that employees are just another commodity like any other production input, the lack of reliable data on employee satisfaction is also partially to blame for the dearth of studies on this field.

From a conceptual perspective, existing theories provide conflicting predictions on the relevance of employee well-being for firm value. On the one hand, traditional ideas stemming out of the so-called scientific management theory formulated by Frederic Winslow Taylor in the beginning of the $20^{\text {th }}$ century argues that workers are a sort of expendable commodity similar to other production inputs (Taylor, 1911, 1914). Consequently, their feelings and level of satisfaction with their firms would not be relevant per se. On the other hand, management behavioral theories with different views on labor relations argue that employee satisfaction is a critical factor for workers' productivity and, consequently, for corporate performance (Barnard, 1938; Follett, 1924; Herzberg, 1959; Maslow, 1943; Mayo, 1933; McGregor, 1960; Ryan \& Deci, 2000). In the past few years, though, the emergence of career community websites that provide crowd-sourced reviews of companies by thousands of employees has allowed more accurate assessments of workers' satisfaction. As a result, a literature aiming to assess the value relevance of human capital based on these sources of information has flourished in the past few years (Chang, Oh, \& Park, 2018; Grennan, 2013; Huang, Meschke, \& Guthrie, 2015; Ji, Rozenbaum, \&Welch, 2017; Symitsi, Stamolampros, \& Daskalakis, 2018; Symitsi, Stamolampros, Daskalakis, \& Korfiatis, 2018).

This paper fits into this emerging literature. Specifically, I investigate the effect of employee satisfaction on corporate performance in Brazil based on an extensive dataset of 114,004 online reviews of its 1,000 largest listed and unlisted firms from 2013 to 2018. The assessments were posted at Brazil's subsidiary of US-based Glassdoor, the world's largest career community website where employees and former employees anonymously review their companies $^{(1)}$.

Overall, I find empirical support for human-resources theories of the firm that see employees as key corporate assets through five main results.

First, in line with previous research in this strand that make use of online reviews (Chang et al., 2018; Huang et al., 2015; Ji et al., 2017; ; Symitsi, Stamolampros, \& Daskalakis, 2018; Symitsi, Stamolampros, Daskalakis, \& Korfiatis, 2018), I find that overall employee satisfaction is positively associated with firm performance after controlling for firm characteristics, industry, and time fixed-effects in System-GMM regressions. Among the four alternative performance indicators used for robustness purposes, the results are particularly consistent for return on equity (ROE) and growth in the ranking position in the prior two years (Growth). The magnitude of the coefficients also suggests that the link between employee satisfaction and performance is likely to be economically relevant. In the case of ROE, for instance, regression coefficients suggest that, ceteris paribus, a company moving from the $10^{\text {th }}$ percentile in terms of employee satisfaction (company rating $=2.70$ ) to the $90^{\text {th }}$ percentile (company rating $=3.86$ ) would be associated with an increase in ROE by $6.4 \%$ per year. For a company whose profitability is equal to the sample's mean of $8.2 \%$, this would represent a substantial increase of about $78 \%$ in its ROE.

Second, among Glassdoor's four dimensions of employee satisfaction - Culture, Compensation and Benefits, Career Opportunities, and Work/Life Balance - the positive relationship with performance is most evident for the Culture dimension, followed by Career Opportunities. For example, companies from the top quartile in culture ratings exhibit an average ROE of $9.9 \%$, about two and half times the average ROE of $4.4 \%$ from the bottom quartile. In addition, companies with better culture ratings advance an average of 4.3 positions in the ranking of the largest 1,000 firms compared to two years before, while culture laggards decline an average of 7.1 positions over the same period. This difference in performance is supported in all econometric procedures with ROE as dependent variable. In one estimate, for instance, a company moving from the $10^{\text {th }}$ percentile in terms of 
culture to the $90^{\text {th }}$ percentile would be associated with an increase in ROE by $10.4 \%$ per year, other things held constant.

The third main result is that, on the other hand, the dimension on Compensation and Benefits was the least relevant for firm performance. Actually, this variable produced contradictory results, with negative coefficients in almost half of the regressions.

Fourth, taken together, the results for the four dimensions of employee satisfaction support the view that intrinsic motivators - represented by culture and career opportunities - are more relevant for superior performance than extrinsic ones expressed by compensation and benefits. This, in turn, suggests that focusing on extrinsic motivators popularized by the carrot and stick approach to management is the least effective way to improve firm performance through superior employee engagement.

The fifth result comes from an analysis in which companies have been segregated in quartiles based on their employee ratings. In this case, the regressions suggest that workplaces characterized by low levels of employee satisfaction destroy significant firm value, while the opposite is not necessarily true in the case of companies that positively stand out in satisfying their employees. These results suggest, therefore, that the influence of employee satisfaction on performance is likely to be asymmetrical, in the sense that employee dissatisfaction is likely to have a clearer impact on performance than employee above-the-average satisfaction.

These findings provide two main contributions to the literature on employee satisfaction, human capital, and the relevance of assessing intangibles in general.

The first is that, to my knowledge, this is the first paper to document a positive link between firm value and employee satisfaction in an emerging economy using online reviews to assess employee satisfaction. This conclusion suggests that putting the human factor at the center of managerial focus is appropriate not only in developed countries such as the US and the UK where most empirical research has been carried out, but also in emerging economies as well. It is also interesting to note that the 2013-2018 period was a particularly turbulent one for the Brazilian economy, with Brazil suffering the greatest recession in its history from 2014 to 2016 (a contraction of about $8 \%$ in the country's GDP). Thus, the results suggest that employee satisfaction may be a particularly significant source of competitive advantage for companies in times of economic distress.

The second contribution is that this is one of the first papers to document an asymmetrical impact of employee satisfaction on performance. Specifically, the results suggest that workplaces characterized by low employee satisfaction are more likely to lead to poor performance than best-in-class companies in terms of employee well-being are likely to produce superior performance.

Because employee welfare is typically one aspect considered in ESG (Environmental, Social, and Corporate Governance) assessments conducted by institutional investors for capital allocation decisions, this paper further contributes to the link between ESG standards and firm performance by showing that employees' online reviews are a value relevant source of information for investors.

This paper is organized as follows. In second section, I provide the conceptual background and review the empirical literature. In third section, I describe the sample, data sources, and research model, as well as the operational definition of the variables. I present and discuss the results in fifth section, with robustness tests being described in sixth section. Final section, in turn, concludes. 


\section{Literature Review}

The argument that the human factor - including employee satisfaction - is relevant for the performance of human organizations such as business enterprises can be seen as almost tautological. Existing theories, though, provide conflicting predictions on the relevance of employee well-being for firm value.

On the one hand, there are traditional ideas from the so-called scientific management theory formulated by Frederic Winslow Taylor in the beginning of the $20^{\text {th }}$ century (Taylor, 1911, 1914) whose roots trace back to Adam Smith's XVIII century pin factory example (2007, Chapter I). This traditional view, created in the context of capital-intense firms typical of the industrial revolution, argues that workers are a sort of expendable commodity just like any other production input. As a result, managers should focus on breaking the work into simple, measurable, and specialized tasks, so they are able to extract the maximum output out of employees while minimizing their costs.

This mindset is based on extrinsic motivators popularized as the carrot and stick approach to management: workers whose production exceeds some predetermined standards receive financial rewards and those who don't meet them are threatened with punishments. Under this view, employee contentment would solely derive from their compensation as well as from the likelihood of being punishment for shirking work. In Taylor's words (1911), "The average workman must be able to measure what he has accomplished and clearly see his reward at the end of each day if he is to do his best" (p. 94). Thus, employee satisfaction under the scientific management paradigm only arises if workers are overpaid or underworked, both of which reduce firm value (Edmans, 2011).

Principal-agent theory, the basis for most research on corporate governance, is built upon this view (Jensen $\&$ Meckling, 1976). Specifically, it argues that managers' role is to maximize firm value by holding employees to the lowest wage rate at which they would be willing to accept a particular job (a concept known as the reservation wage in labor economics). If, for any reason, managers opt to pay above market rates or accept employees to engage in excessive slack time, then they would be incurring into agency costs borne by shareholders.

On the other hand, there are management behavioral theories with different views on labor relations (Barnard, 1938; Follett, 1924; Herzberg, 1959; Maslow, 1943; Mayo, 1933; McGregor, 1960; Ryan \& Deci, 2000). They argue that employee satisfaction - primarily based on intrinsic motivators such as a sound organizational culture, a sense of purpose, and the perspective of developing oneself professionally - is a critical factor for workers' productivity and, consequently, for firm performance to the benefit of shareholders.

These theories point out that seeing employees as a key organization asset is particularly true in modern workplaces, in which employees are involved in complex tasks such as decision-making, relationship-building, critical thinking, innovation, and problem-solving. Thus, because the current workplace chiefly requires cognitive and emotional abilities instead of physical ones, human capital has replaced physical capital as the main source of sustainable competitive advantage for companies.

In spite of the relevance of this debate for the way companies are managed and governed, empirical research to investigate the proposition that the traditional view of the firm should give place to a human-centered one has only taken off in the past few years.

One of the first studies was carried out by Filbeck and Preece (2003). They analyzed the stock price impact of a firm's inclusion in the 100 Best Places to Work for in America list compiled by the Great Place to Work Institute. By means of event study tests, they found a significant positive market reaction on the day of the announcement. This led them to conclude that "...the marketplace believes that satisfied employees may lead to satisfied shareholders" (p. 791).

Edmans (2011) carried out a subsequent study on this field. He analyzed the relationship between employee satisfaction and long-run stock returns by using a value-weighted portfolio of the 100 Best Companies to Work for in America. He found that such portfolio earned an annual four-factor alpha of 3.5\% from 1984 to 2009, or $2.1 \%$ above industry benchmarks. He also observed that Best Companies for employees exhibited significantly 
more positive earnings surprises and announcement returns. His conclusion, therefore, is that firms with high levels of employee satisfaction generate superior long-horizon returns. Using a different methodology in a related paper, Edmans (2012) also found that companies listed in the U.S. 100 Best Companies to Work For generated 2.3\% to $3.8 \%$ higher stock returns per year than their industry peers from 1984 through 2011.

Guiso, Sapienza and Zingales (2015) also contributed significantly to this literature. They analyzed data from 1,000 American companies between 2007 and 2011 that are part of the Best Places to Work For list. About 400,000 employees evaluated their own companies through 58 statements related to different aspects of their workplace. Their key conclusion was that the level of employee agreement with two statements related to the integrity of their leaders proved to be strong predictors of corporate performance in terms of higher productivity, profitability, better industrial relations, and even higher level of attractiveness to prospective job applicants.

Up to this point, most papers in this field measured employee satisfaction by third-party reports such as the Best Places to Work For lists. However, as detailed in the next section, these data sources have relevant drawbacks, such as its perverse incentive for firms to manipulate the responses of their employees so they could be included in these publications. This research approach changed with the emergence of career community websites such as Glassdoor and Indeed. These websites provided crowd-sourced reviews of companies by thousands of current and former workers, thus likely leading to more accurate assessments of employee satisfaction (the next section details this argument).

One of the pioneer studies in this field using career community databases was Grennan (2013). After constructing measures of corporate culture based on employee reviews at Glassdoor, she concludes that organizational culture is an important channel through which shareholder governance affects firm value. Specifically, she shows that stronger shareholder governance changes aspects of culture by leading to a greater results-orientation but less customer-focus, integrity, and collaboration. This augmented results-orientation leads managers to concentrate on easy-to-observe benchmarks which, in turn, allows shareholders to initially realize financial gains through increases in sales, profitability, and payouts. Over time, though, this change in culture leads managers to overlook harder-to-measure intangibles, impairing important drivers of long-term value such as costumer satisfaction and employee integrity. Overall, she finds that initial gains created by shareholder governance are reversed and that firm value declines $1.4 \%$ through this corporate culture channel.

Huang, Meschke and Guthrie (2015) also resort to online reviews to investigate the role of culture in family firms and its implications for firm value. They use more than 100,000 surveys collected by Glassdoor between 2008 and 2012 and find that find that employees who work for firms with active founders rate their companies higher than employees in nonfamily firms, particularly if the founder runs the company. They also find that employee assessments are positively associated with subsequent firm performance measured by Tobin's q and return on assets (ROA). Thus, their findings provide evidence that family firms exhibit a human-capital-enhancing culture that leads to superior corporate performance.

Corroborating the idea that this line of research has taken off in the past few years due to the emergence of websites where employees can anonymously review their companies, most papers in this strand have been published in the biennium 2017-2018.

Symitsi, Stamolampros and Daskalakis (2018) performed a portfolio analysis using online reviews on Glassdoor from 2009 to 2016 to decide which U.S. stocks to include in a value-weighted portfolio of companies characterized by high employee satisfaction. Subsequently, they found that this portfolio generated a positive and significant monthly four-factor alpha of $1.35 \%$ over an eight-year period as well as resulted in superior profitability (ROA) and firm value (Tobin's Q). Thus, they conclude that employee satisfaction positively impacts corporate performance and that this valuable intangible is not fully priced in the stock market. In a related paper based on 35,231 reviews for 164 public and private British firms, Symitsi, Stamolampros, Daskalakis and Korfiatis (2018) finds that employee satisfaction also produces positive impacts on firm profitability in the UK, and that this is still not fully recognized by equity investors.

Ji, Rozenbaum and Welch (2017) explored the impacts of employee satisfaction from a different angle. They covered Glassdoor's 1,112,476 employee ratings of 14,282 public firms over the 2008-2015 period to 
investigate whether financial reporting risk is associated with job satisfaction and company culture. They find that firms with lower levels of job satisfaction and lower levels of culture and values are more likely to be subjected to SEC fraud enforcement actions and securities class action lawsuits. In addition, they notice that a lower rated culture is associated with an increased likelihood of narrowly meeting or beating market earnings expectations. Thus, they find strong evidence that the work environment, as perceived by employees, appears to play a critical role in financial reporting risk and corporate fraud.

Chang, Oh and Park (2018) also investigate the impacts of employee satisfaction from a different perspective, this time focusing the creation of shareholder value around mergers. By using over a million reviews of S\&P 1,500 firms posted between 2008 and 2017 on Glassdoor, they find that acquirers with high employee satisfaction experience stronger announcement returns and improvements in operating performance. Conversely, they find that acquirers with low employee satisfaction are more likely to encounter disruptive events like employment-related lawsuits or changes to management following merger announcements. Among the five Glassdoor sub-categories, they observe that employee perceptions of career opportunities have the most reliable effect on post-merger performance. In aggregate, their results suggest that the positive implications of employee satisfaction on post-merger performance are even more pronounced when employees' career concerns are well taken care of.

To conclude, Edmans, Li and Zhang (2014) carried out the first cross-country study on this field. Using lists of the Best Companies to Work For from 14 countries, they show that employee satisfaction is associated with positive abnormal returns in countries with high labor market flexibility, such as the US and UK, but not in countries with low labor market flexibility, such as Germany. In their view, their results are consistent with high employee satisfaction being a valuable tool for recruitment, retention, and motivation in flexible labor markets, where firms face fewer constraints on hiring and firing. In regulated labor markets, though, legislation is more likely to provide minimum standards for workers' welfare, which may lead to lower marginal benefits of expenditure on employee welfare. Thus, there may be relevant nuances in the employee satisfaction-stock market performance across countries.

\section{Methodology}

\section{Sample and data sources}

My sample is the result of the merger of two databases. The first comes from the Valor 1,000 ranking published on an annual basis by Valor Economico, Brazil's main business newspaper (https://valor.globo.com). This list identifies the 1,000 largest Brazilian companies by revenues, both listed and unlisted. It also provides some corporate and financial data for these firms. As the vast majority of Brazil's largest companies are unlisted, no stock market indicators are available for this sample. My analysis covers six years from 2013 to 2018, which results in a database with 6,000 firm-year observations from 1,939 different firms.

The second database comes from the Brazilian subsidiary of US-based Glassdoor, the world's largest company-ratings and recruiting website (www.glassdoor.com.br). As described in the previous section, Glassdoor database has been used by many papers in this field such as Grennan (2013), Huang et al. (2015), Ji et al. (2017), Symitsi, Stamolampros and Daskalakis (2018), Symitsi, Stamolampros, Daskalakis and Korfiatis (2018), and Chang et al. (2018).

Glassdoor asks employees to anonymously comment and report their satisfaction about their firms using a 5-point Likert scale where 1 corresponds to the worst reviews and 5 to the best ones. Companies are rated along four dimensions: Culture, Compensation \& Benefits, Career Opportunities, and Work/Life Balance. In addition, employees are required to indicate their overall satisfaction with their companies as well as if they recommend them to friends. 
Although all employee assessments are made publicly-available at Glassdoor's website for all registered users, the website denied our request to send its full database for the purpose of this research on allegations that this was not allowed by its internal policies. As a result, an algorithm was created in order to automate data extraction from the website.

I retrieved all 307,242 employee reviews posted at Glassdoor's Brazilian website from 2013 to 2018 for 5,814 firms. About two-thirds $(67.8 \%$ or 208,282$)$ of the reviews were posted by current employees, while around one-third (32.2\% or 98.960$)$ were posted by former employees.

By merging Valor 1,000 and Glassdoor databases, I end up with a final sample of 3,116 firm-year observations for 1,031 different firms based on the reviews of 114,004 employees. Each firm received an average of 110.5 employee reviews over this period (36.6 number of reviews per firm-year on average). For each given year, I aggregated all ratings to create a firm-year measure of employee satisfaction.

The use of online employee reviews from career community websites such as Glassdoor has many advantages over the use of corporate social reports or external surveys such as Great Places to Work best workplaces list, the two traditional data sources for research on this field.

To begin with, corporate social reports are typically voluntary. This may lead to sample bias, as some firms are more likely than others to disclose it. As an example, firms with worst human relations record may be more likely to publish such reports (sometimes with not so realistic figures) in order to use them as a public relations tool. Alternatively, firms under financial constraints may be less likely to disclose these reports due to lack of resources.

External surveys, in turn, also suffer from other relevant drawbacks. In many cases, such as the Best Places to Work For lists, companies must pay to be part of such surveys. As explained by Grennan (2013), this obviously creates perverse incentives for companies to manipulate the responses of its employees in order to receive better assessments. In addition, external surveys are infrequent (usually published once a year) and very limited in the number of covered firms.

Using crowd-sourced online reviews that reflect perceptions of thousands of different employees on their firms do not have any of these handicaps. On the contrary. Empirical evidence shows that employee perceptions matter significantly more to firm value than firms' stated values (Guiso, Sapienza, \& Zingales, 2015). Thus, having direct access to employee opinions is likely to uncover the collective wisdom about how workers truly feel about their workplaces, which would lead to better constructs of employee satisfaction than corporate reports.

In this research, for instance, my indicators of employee satisfaction are based on more than 100,000 different assessments from a relatively high number of firms over a significant time window. This has allowed, in turn, the creation of a panel dataset with substantial cross-sectional and time-series variation.

On the other hand, it is important to recognize that data from social media may also be subject to sample bias. One of the commonly cited limitations comes from the argument that unhappy employees, particularly former ones, may have a greater incentive to post negative comments. Glassdoor's policies aims to alleviate such concern. Firstly, the website uses a give-to-get model that requires all users to post a full company review and salary report in order to get unlimited access. This allows it to expand its user base and reduce the weight of unrepresentative reviews from dissatisfied employees. The website also claims to take a series of measures to validate users' identities and relationships with their companies. In addition, all reviews are read by Glassdoor's moderation team before being posted and the website states in its community guidelines to never suppress, edit, or delete content because of its rating. 


\section{Operational definition of the main variables}

\section{Dependent variables on corporate performance}

Corporate performance can be defined in many ways. In this study, I use four alternative measures for robustness purposes: Return on equity (ROE): net income divided by shareholders' equity; Return on assets (ROA): operating income divided by total assets; Ebitda margin (Ebitda): earnings before interest, tax, depreciation, and amortization divided by net revenues; and, Growth in the ranking of 1,000 largest companies in the prior two years (Growth): ranking position in the Valor 1,000 list two years before minus its current position.

\section{Explanatory variables on employee satisfaction}

As detailed in the previous section, employee satisfaction is measured by the average rating on a scale of 1 to 5 of: Overall Employee Satisfaction (OV_SATISFCT): average score of employees when asked on their satisfaction with their firms; Company recommendation for others (RECOMMEND): percentage of employees who recommend their companies; Culture, Compensation and Benefits, Career Opportunities, and Work/Life Balance (CULTURE, COMP_BEN, CAREER_OP, and Q_LIFE): average score for the dimensions Culture, Compensation and Benefits, Career Opportunities, and Work/Life Balance, respectively.

\section{Control variables}

The Valor 1,000 ranking is composed of a majority of unlisted and closely-held firms. As a result, public information about these companies is very limited and it is possible to use of an ideal set of controls. In any case, I carried out best efforts in order to control for the following attributes that might simultaneously influence the main variables of interest: Firm size (SIZE): natural logarithm of total assets; Financial leverage (DEBT_LEV): short term debt and current portion of long-term debt plus long-term debt divided by total assets; Country source of the company's capital (COUNTRY): dummy variable taking the value of (1) for with Brazilian capital, and (0) for companies with foreign capital; Geographical location of the company's headquarters (SOUTHEAST_ REGION): dummy variable taking the value of (1) if the firm's headquarters is located in Brazil's Southeast region (the most developed of the country, accounting for about $60 \%$ of Brazil's GDP), and (0) otherwise; Industry controls: Twenty-seven industry dummies based on the Valor 1,000 newspaper classification; and, Time controls: Yearly dummies from 2013 to 2018.

It is important to highlight that my choice of firm characteristics used as control variables was based on the previous literature most closely related to our paper (Chang et al., 2018; Huang et al., 2015; Ji et al., 2017; Symitsi, Stamolampros, \& Daskalakis, 2018; Symitsi, Stamolampros, Daskalakis, \& Korfiatis, 2018) and on a rationale linking them to both variables of interest. Larger firms, for example, are likely to have more resources to spend on employee benefits and workplace amenities, which may influence employee satisfaction. In addition, they are likely to have more market power, which may lead to higher profitability. Financially indebted companies, on the other hand, may have less resources available to invest in their employees. Employees working for these companies may also suffer a higher level of stress due to greater uncertainty about the future prospects of the organization. At the same time, the level of corporate debt may also impact its profitability. Ownership structure may also influence both employee satisfaction and firm performance. Specific characteristics of the shareholders, such as companies under foreign control, are likely to have a different approach and practices towards employees, which may impact the level of employee satisfaction. At the same time, these companies may be able to access to different funding sources and may have time-horizon for investments, which could impact profitability levels.

All variable definitions are provided in Table 1. 
Table 1

\section{Research Variables and Their Operational Definitions}

\begin{tabular}{|c|c|c|c|c|}
\hline Variable & Type & Acronym & Operational definition & Firm-year observations \\
\hline Return on Equity & Dependent & ROE & $\begin{array}{l}\text { Net income / shareholders' } \\
\text { equity }\end{array}$ & 5,389 \\
\hline Return on Assets & Dependent & ROA & Operating income / total assets & 5,497 \\
\hline Ebitda Margin & Dependent & EBITDA & $\begin{array}{l}\text { Earnings before interest, tax, } \\
\text { depreciation, and amortization / } \\
\text { net revenues }\end{array}$ & 5,448 \\
\hline $\begin{array}{l}\text { Growth in the } \\
\text { Valor ranking of } \\
\text { largest } 1,000 \\
\text { companies in the } \\
\text { prior two years }\end{array}$ & Dependent & GROWTH & $\begin{array}{l}\text { Position in the ranking of the } \\
1,000 \text { largest companies two } \\
\text { years earlier minus its current } \\
\text { position }\end{array}$ & 5,056 \\
\hline $\begin{array}{l}\text { Overall Employee } \\
\text { Satisfaction }\end{array}$ & Explanatory & OV_SATISFCT & $\begin{array}{l}\text { Average score of employees on } \\
\text { a } 1-5 \text { scale about their overall } \\
\text { satisfaction with their firms }\end{array}$ & 3,116 \\
\hline $\begin{array}{l}\text { Company } \\
\text { recommendation } \\
\text { for others }\end{array}$ & Explanatory & RECOMEND & $\begin{array}{l}\text { Percentage of employees who } \\
\text { recommend the company to } \\
\text { others }\end{array}$ & 3,085 \\
\hline Culture & Explanatory & CULTURE & $\begin{array}{l}\text { Average score of employees for } \\
\text { the dimension Culture on a 1-5 } \\
\text { scale }\end{array}$ & 3,116 \\
\hline $\begin{array}{l}\text { Compensation } \\
\text { and Benefits }\end{array}$ & Explanatory & COMP_BEN & $\begin{array}{l}\text { Average score of employees for } \\
\text { the dimension Compensation } \\
\text { and Benefits on a } 1-5 \text { scale }\end{array}$ & 3,116 \\
\hline $\begin{array}{l}\text { Career } \\
\text { Opportunities }\end{array}$ & Explanatory & CAREER_OP & $\begin{array}{l}\text { Average score of employees for } \\
\text { the dimension Career } \\
\text { Opportunities on a } 1-5 \text { scale }\end{array}$ & 3,116 \\
\hline $\begin{array}{l}\text { Work/Life } \\
\text { Balance }\end{array}$ & Explanatory & Q_LIFE & $\begin{array}{l}\text { Average score of employees for } \\
\text { the dimension Work/Life } \\
\text { Balance on a } 1-5 \text { scale }\end{array}$ & 3,116 \\
\hline Firm size & Control & SIZE & Natural logarithm of total assets & 5,599 \\
\hline Financial leverage & Control & DEBT_LEV & $\begin{array}{l}\text { Gross debt (short term debt and } \\
\text { current portion of long-term } \\
\text { debt + long term debt) / total } \\
\text { assets }\end{array}$ & 5,599 \\
\hline $\begin{array}{l}\text { Country source of } \\
\text { the company's } \\
\text { capital }\end{array}$ & Control & COUNTRY & $\begin{array}{l}1 \text { for with Brazilian capital; } 0 \text {, } \\
\text { for companies with foreign } \\
\text { capital }\end{array}$ & 6,000 \\
\hline
\end{tabular}

Continues 


\section{Table 1 (continued)}

\begin{tabular}{|c|c|c|c|c|}
\hline Variable & Type & Acronym & Operational definition & Firm-year observations \\
\hline $\begin{array}{l}\text { Region of the } \\
\text { company's } \\
\text { headquarters }\end{array}$ & Control & $\begin{array}{c}\text { SOUTHEAST }_{-} \\
\text {REGION }\end{array}$ & $\begin{array}{l}1 \text { if the firm's headquarters is } \\
\text { located in Brazil's Southeast } \\
\text { region (the most developed } \\
\text { accounting for about } 60 \% \text { of } \\
\text { Brazil's GDP); } 0 \text {, otherwise }\end{array}$ & 6,000 \\
\hline Industry & Control & $\begin{array}{l}\text { IND_- } \\
\text { DUMMIES }\end{array}$ & $\begin{array}{l}\text { Twenty-seven industry dummy } \\
\text { variables using the Valor } 1,000 \\
\text { newspaper classification }\end{array}$ & 6,000 \\
\hline Time & Control & $\begin{array}{l}\text { YEAR_- } \\
\text { DUMMIES }\end{array}$ & $\begin{array}{l}\text { Dummy variables defined as } \\
\operatorname{YEAR}(t)=1 \text { in the } \mathrm{t} \text {-th year and } \\
\operatorname{YEAR}(t)=0 \text { otherwise, with } t \\
=1, \ldots, 6(2013, \ldots, 2018)\end{array}$ & 6,000 \\
\hline
\end{tabular}

\section{Research model and data analysis}

The baseline model to analyze the influence of employee satisfaction on corporate performance comes from the following linear specification:

$$
\begin{aligned}
& \text { Performance }_{\text {it }} \\
& \qquad \begin{array}{l}
= \\
\\
+\sum_{k=1}^{27} \delta_{k} \times I N D_{k i}+\sum_{l=1}^{6} \gamma_{l} \times Y \text { Company_Rating }_{i t}+\beta_{2} \times \text { Performance }_{i t-1}+n_{i}+u_{i t}^{n} \beta_{j} \times C V_{j i t}
\end{array}
\end{aligned}
$$

Where: Performance $i t=$ measure of performance of the $i^{\text {th }}$ firm at time $t$. Alternative indicators: return on equity, return on assets, Ebitda margin, or growth in ranking position of the largest 1,000 companies in the previous two years; $\overline{\text { Company_Ratıng }}_{i t}=$ average company rating by employees of the $i^{\text {th }}$ firm at time $t$ on a scale of 1 to 5. Alternative indicators: overall employee satisfaction, percentage of company recommendation for others, culture, compensation and benefits, career opportunities, and work/life balance dimensions; Performance ${ }_{i t-1}=$ performance of the $i^{\text {th }}$ firm at time $t-1 ; C V_{j i}=$ set of control variables with firm-specific characteristics of the $i^{\text {th }}$ firm at time $t$ : firm size; financial leverage; country source of the company's capital; and geographical location of the company's headquarters; $I N D_{k i}=$ set of twenty-seven industry dummy variables of the $i^{\text {th }}$ firm to control for industry heterogeneity; $Y E A R_{l t}=$ set of six year dummy variables to control for the heterogeneity across time; $n_{i}=$ firm specific and time-invariant effect of the $i^{\text {th }}$ firm (non-observable fixed effect); and, $u_{i t}=$ random error term of the $i^{\text {th }}$ firm at time $t$.

The baseline model raises several endogeneity concerns, which I endeavor the best efforts to address. Firstly, a better company performance may lead employees to deliberately or unconsciously assign better ratings to their firms. Thus, reverse causality may take place. In addition, the database mostly composed of closely-held firms has relevant data limitations on firm-level attributes that are usually important for research on this field. Thus, omitted variables affecting both corporate performance and employee satisfaction may also take place.

I try to mitigate these endogeneity concerns by using alternative operational definitions for performance and employee satisfaction, as well as by estimating the relationship between the main variables of interest using four different econometric approaches in increasing order of complexity: pooled OLS regressions, dynamic OLS regressions (controlling for past performance), fixed-effects models, and System-GMM (generalized method of 
moments). Among these, dynamic GMM regressions constitute the most reliable procedure employed in my analysis to mitigate for endogeneity concerns.

In all regressions, I test for the significance of the coefficients using standard errors robust to heteroskedasticity clustered by firm. I also restrict the analysis to companies with a minimum of 5 employee reviews per year in order to reduce potential biases in the assessments and test alternative minimums in robustness checks. Despite these efforts to mitigate endogeneity concerns, there may be still certain endogeneity issues that have not been properly addressed. As a result, it is not possible to rule out that some results may be driven by spurious correlation nor claim causality.

\section{Results}

\section{Descriptive and quartile analysis}

Table 2 provides descriptive statistics on the research variables. In terms of performance, the median firmyear observation of our sample exhibits a ROE of $10.4 \%$ and a ROA of $5.7 \%$. The position in the ranking of the 1,000 largest companies tend to be relatively stable for most firms, as the median company advances a single place compared to its ranking position two years before.

Table 2

Descriptive Statistics on Research Variables

\begin{tabular}{|c|c|c|c|c|c|c|c|c|c|}
\hline Variable & Acronym & Obs. & Mean & $\begin{array}{l}\text { Standard } \\
\text { Deviation }\end{array}$ & Min & $\mathrm{P} 25$ & Median & P75 & Max \\
\hline Return on Equity & ROE & 5,389 & $8.2 \%$ & $30.0 \%$ & $-113.5 \%$ & $1.5 \%$ & $10.4 \%$ & $20.4 \%$ & $73.4 \%$ \\
\hline Return on Assets & ROA & 5,497 & $7.1 \%$ & $11.2 \%$ & $-17.7 \%$ & $1.0 \%$ & $5.7 \%$ & $11.8 \%$ & $42.0 \%$ \\
\hline Ebtida Margin & EBITDA & 5,448 & $13.4 \%$ & $14.9 \%$ & $-14.2 \%$ & $4.2 \%$ & $9.8 \%$ & $18.9 \%$ & $59.7 \%$ \\
\hline $\begin{array}{l}\text { Growth in the two prior } \\
\text { years }\end{array}$ & GROWTH & 5,056 & 0.8 & 81.7 & -494 & -25 & 1 & 29 & 628 \\
\hline $\begin{array}{l}\text { Overall Employee } \\
\text { Satisfaction }\end{array}$ & OV_SATISFCT & 3,116 & 3.29 & 0.49 & 1 & 3 & 3.3 & 3.6 & 5 \\
\hline $\begin{array}{l}\text { Company } \\
\text { recommendation }\end{array}$ & RECOMEND & 3,085 & $82.3 \%$ & $15.3 \%$ & $17 \%$ & $74 \%$ & $84 \%$ & $95 \%$ & $100 \%$ \\
\hline Culture & CULTURE & 3,116 & 3.37 & 0.63 & 1 & 3 & 3.4 & 3.77 & 5 \\
\hline $\begin{array}{l}\text { Compensation and } \\
\text { Benefits }\end{array}$ & COMP_BEN & 3,116 & 3.46 & 0.59 & 1 & 3.05 & 3.5 & 3.86 & 5 \\
\hline Career Opportunities & CAREER_OP & 3,116 & 2.96 & 0.62 & 1 & 2.6 & 3 & 3.33 & 5 \\
\hline Work/Life Balance & Q_LIFE & 3,116 & 3.35 & 0.62 & 1 & 3 & 3.3 & 3.75 & 5 \\
\hline $\begin{array}{l}\text { Firm Size (Total Assets } \\
\text { in BRL Million) }\end{array}$ & SIZE & 5,599 & 5,020 & 29,621 & 2.3 & 455.2 & 979.8 & $2,826.2$ & 900,135 \\
\hline $\begin{array}{l}\text { Financial leverage } \\
\text { (Gross debt / assets) }\end{array}$ & DEBT_LEV & 5,599 & 0.44 & 0.85 & 0 & 0.03 & 0.13 & 0.39 & 4.27 \\
\hline $\begin{array}{l}\text { Source of the capital } \\
(\text { Brazil = 1) }\end{array}$ & COUNTRY & 6,000 & 0.77 & 0.42 & 0 & 1 & 1 & 1 & 1 \\
\hline $\begin{array}{l}\text { Region of headquarters } \\
(\text { Southeast }=1)\end{array}$ & REGION & 6,000 & 0.64 & 0.48 & 0 & 0 & 1 & 1 & 1 \\
\hline
\end{tabular}


Employee overall satisfaction has a mean value of 3.29 on a 1-5 scale throughout the research period, with the company at the $25^{\text {th }}\left(75^{\text {th }}\right)$ percentile exhibiting a value of 3.00 (3.60). An average of 82.3 employees recommend their companies to others, ranging from $17 \%$ for the worst assessed firm to $100 \%$ for the better rated ones. The average scores for the dimensions Culture, Compensation \& Benefits, and Work/Life Balance are relatively similar, ranging from 3.35 to 3.46. The exception comes from the dimension Career Opportunities, which shows a significantly lower mean value of 2.96 .

Companies from the sample exhibit median (mean) total assets of BRL 980 million (BRL 5.0 billion), around USD 250 million (USD 1.4 billion). Around 77\% of the companies are financed by Brazilian capital, while the remaining is controlled by foreigners. In line with the country GDP, around 64\% of the companies are based in the richest Southeast region, while the rest is based in the other four regions of the country.

The initial inspection of the data concludes with correlations and quartile analysis. Correlations between our variables of interest and the other research variables are presented in two matrices. The first shows the relationship between employee satisfaction and corporate performance.

As shown in Table 3, there is a significant positive correlation at the $1 \%$ level between overall employee satisfaction and ROE, as well as a positive correlation at the 5\% with Ebitda. On the other hand, the correlations with ROA and Growth in ranking position, although positive, are not statistically significant. Concerning the four dimensions of employee satisfaction, two stand out in terms of strongest positive correlations with performance: Culture and Career Opportunities. In both cases, there is a positive correlation at least at the 5\% level with all measures of firm performance. On the other, it is worth noticing that the dimension on Compensation \& Benefits is the only one without significant positive correlations with performance. Taken together, these results highlight the relevance of investing in intrinsic motivators represented by culture and career opportunities compared to investments in extrinsic motivators represented by compensation and benefits.

Table 3

Correlation Matrix: Employee Satisfaction and Corporate Performance

\begin{tabular}{lcccccc}
\hline & OV_SATISFCT & RECOMEND & CULTURE & COMP_BEN & CAREER_OP & Q_LIFE \\
\hline ROE & $0.0638^{* * *}$ & $0.0290^{*}$ & $0.0886^{* * *}$ & -0.0001 & $0.0719^{* * *}$ & $0.0432^{* *}$ \\
\hline ROA & 0.0326 & $0.0392^{* *}$ & $0.0595^{* * *}$ & $-0.0402^{*}$ & $0.0788^{* * *}$ & 0.0043 \\
\hline EBITDA & $0.049^{* *}$ & $0.0537 * * *$ & $0.0530^{* *}$ & 0.0253 & $0.0511^{* *}$ & 0.0146 \\
\hline GROWTH & 0.0290 & -0.0021 & $0.0510^{* *}$ & -0.0071 & $0.0626^{* * *}$ & 0.0250 \\
\hline
\end{tabular}

Note. The table exhibits Pearson correlation coefficients. Table 1 details the operational definitions of all variables. We restrict our analysis for firms with at least five reviews in a certain year. $* * * * *$ and $*$ denote significance at the 1,5 , and $10 \%$ levels, respectively.

Table 4, in turn, exhibits the correlations between employee satisfaction and the other research variables. It shows that larger firms with lower debt levels and foreign capital receive, on average, better employee scores (there is no clear correlation with the geographical location of the companies). It is interesting to observe, therefore, that companies controlled by Brazilians exhibit, on average, lower levels of employee satisfaction than those with foreign capital. 
Table 4

\section{Correlation Matrix: Employee Satisfaction and Other Corporate Attributes}

\begin{tabular}{|c|c|c|c|c|c|c|}
\hline & OV_SATISFCT & RECOMEND & CULTURE & COMP_BEN & CAREER_OP & Q_LIFE \\
\hline SIZE & $0.1566 * * *$ & $0.0978 * * *$ & $0.1474 * * *$ & $0.1635 * * *$ & $0.1223 * * *$ & $0.0708 * * *$ \\
\hline DEBT_LEV & $-0.0998 * * *$ & $-0.0744 * * *$ & $-0.0996 * * *$ & $-0.0689 * * *$ & $-0.0609 * * *$ & $-0.0910 * * *$ \\
\hline AV_SALARY & $0.3306 * * *$ & $0.2243 * * *$ & $0.2090 * * *$ & $0.4585 * * *$ & $0.0723 * * *$ & $0.3270 * * *$ \\
\hline COUNTRY_BRAZIL & $-0.1239 * * *$ & $-0.0721 * * *$ & $-0.1259 * * *$ & $-0.1235 * * *$ & $-0.0787 * * *$ & $-0.0696 * * *$ \\
\hline REGION_SOUTHEAST & -0.0092 & -0.0279 & -0.0036 & $0.0404 * *$ & -0.0230 & $-0.0429 * *$ \\
\hline
\end{tabular}

Note. The table exhibits Pearson correlation coefficients. Table 1 details the operational definitions of all variables. We restrict our analysis for firms with at least five reviews in a certain year. $* * *, * *$ and $*$ denote significance at the 1,5 , and $10 \%$ levels, respectively.

I also carried out a quartile analysis to have a deeper understanding on the correlations between employee satisfaction and firm performance. In this case, for each indicator of employee satisfaction, I segregate firms into four groups based on their ratings $(\mathrm{Q} 1$ for the first quartile with lower ratings, Q2, Q3, and Q4 for the fourth quartile with highest ratings). After segregating companies in quartiles, I then compared the performance of the groups through two-sample difference of means tests. Table 5 presents these comparisons for the Overall Satisfaction variable. 
Table 5

\section{Subgroup Analysis: Overall Employee Satisfaction and Financial Performance}

\begin{tabular}{|c|c|c|c|c|c|c|}
\hline \multirow[b]{2}{*}{$\begin{array}{l}\text { Performance } \\
\text { Variable }\end{array}$} & \multirow[b]{2}{*}{ Legend } & \multicolumn{5}{|c|}{ Overall employee satisfaction on a 1-5 scale (OV_SATISFCT) } \\
\hline & & $\begin{array}{c}\text { BOTTOM OV_SATISFCT } \\
\text { Q1 } \\
\text { Mean overall satisfaction = } \\
2.67\end{array}$ & $\begin{array}{c}\text { Q2 } \\
\text { Mean overall } \\
\text { satisfaction }=3.15\end{array}$ & $\begin{array}{c}\text { Q3 } \\
\text { Mean overall satisfaction } \\
=3.44\end{array}$ & $\begin{array}{c}\text { TOP OV_SATISFCT } \\
\text { Q4 } \\
\text { Mean overall satisfaction } \\
=3.88\end{array}$ & $\begin{array}{l}t \text {-value } \\
\text { difference of } \\
\text { means }\left(Q^{4-}\right. \\
Q 1)\end{array}$ \\
\hline \multirow{3}{*}{ ROE } & Mean & $4.4 \%$ & $6.4 \%$ & $7.6 \%$ & $8.5 \%$ & \\
\hline & $S D$ & $(33.8 \%)$ & $(31.1 \%)$ & $(29.7 \%)$ & $(30.4 \%)$ & $2.397 * * *$ \\
\hline & $n$ & $n=697$ & $n=683$ & $n=674$ & $n=703$ & \\
\hline \multirow{3}{*}{ ROA } & Mean & $5.4 \%$ & $7.1 \%$ & $6.7 \%$ & $7.0 \%$ & \\
\hline & $S D$ & $(11.2 \%)$ & $(11.4 \%)$ & $(11.1 \%)$ & $(10.5 \%)$ & $2.845^{* * * *}$ \\
\hline & $n$ & $n=726$ & $n=687$ & $n=682$ & $n=699$ & \\
\hline \multirow{3}{*}{ EBITDA } & Mean & $11.7 \%$ & $14.0 \%$ & $14.0 \%$ & $15.0 \%$ & \\
\hline & $S D$ & $(13.8 \%)$ & $(14.6 \%)$ & $(14.9 \%)$ & $(15.9 \%)$ & $4.130 * * *$ \\
\hline & $n$ & $n=720$ & $n=696$ & $n=682$ & $n=703$ & \\
\hline \multirow{3}{*}{ GROWTH } & Mean & -8.9 & -0.6 & 0.8 & 1.6 & \\
\hline & $S D$ & $(78.1)$ & $(61.8)$ & (63.9) & $(70.4)$ & $2.638 * * *$ \\
\hline & $n$ & $n=684$ & $n=702$ & $n=703$ & $n=705$ & \\
\hline
\end{tabular}

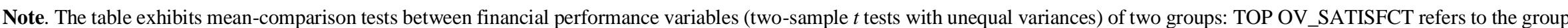

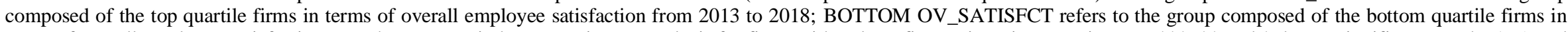

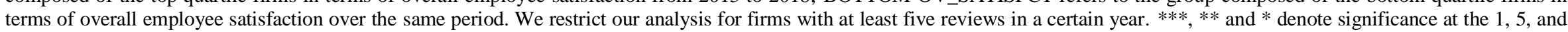
$10 \%$ levels, respectively. 
In Table 5, the results are quite clear: for all performance variables, companies from the top quartile in terms of overall employee satisfaction outperform those from the other quartiles, particularly those from the first quartile composed of the companies with lower scores. Let's take the example of ROE. Companies from Q4 (mean overall satisfaction of 3.88) exhibit an average return on equity of 8.5\%, about twice as much as those belonging to Q1 (mean overall satisfaction of 2.67 ; average $\mathrm{ROE}=4.4 \%$ ). This difference in performance is statistically significant at the $1 \%$ level and the same is true for the three alternative performance indicators (ROA, Ebitda, and Growth). It is also possible to observe that, as employee satisfaction increases across the quartiles, firm performance also improves accordingly. In the case of ROE, for example, Q2 average return on equity is $6.4 \%$, significantly lower than Q3 average ROE of 7.6\%.

This pattern is the same for the alternative variable on overall employee satisfaction related to the percentage of workers recommending the firm to others. It is also the same for the dimensions on Culture, Career Opportunities, and Work/Life Balance (all tables omitted for space reasons and available upon request). Among these dimensions, the difference in performance among quartiles is most evident for Culture. In this case, companies from the top quartile in Culture exhibit an average ROE of 9.9\%, about two and half times the average ROE of $4.4 \%$ from the bottom quartile. In addition, companies with better culture reviews advanced on average 4.3 positions in the ranking of the largest 1,000 Brazilian firms compared to two years before, while the laggards in terms of culture ratings declined an average of 7.1 positions over the same period. Once again, the notable exception comes from the dimension on Compensation and Benefits. In this instance, there was not a clear pattern between employee ratings and performance indicators (the relationship was positive for Ebitda, but not significant for the other variables). Thus, the results from this descriptive section suggest that focusing on extrinsic motivators is the least effective way to improve firm performance through superior employee engagement.

\section{Regression analysis}

Table 6 reports the results of different regression models aiming to analyze the effect of employee satisfaction on firm performance. The dependent variables are ROE (models 1-4), ROA (models 5-8), and the Growth in the ranking of the largest 1,000 Brazilian companies in the prior two years (models 9-12). The explanatory variable of interest is the overall company rating on a 1-5 scale at Glassdoor. Other independent variables are used as controls. As described in the previous section, I estimate the relationship between the main variables of interest through four econometric approaches in increasing order of complexity. Models 1, 5, and 9 report estimates from OLS regressions with robust White-corrected standard errors. Models 2, 6, and 10 report estimates from dynamic OLS regressions with lagged performance variables. Models 3, 7, and 11 show estimates from Fixed Effects regressions. Models 4, 8, and 11 are dynamic panel data models estimated through SystemGMM regressions. In the GMM regressions, I use variables lagged two to four years as instruments for the endogenous variables and assume that all explanatory variables except geographic location, country source of the company's capital, industry, and year dummies are endogenous. 
Table 6

\section{The Effect of Overall Employee Satisfaction on Company Performance}

\begin{tabular}{|c|c|c|c|c|c|c|c|c|c|c|c|c|}
\hline \multirow{2}{*}{$\frac{\text { Dependent Variable }}{\text { Method }}$} & \multicolumn{4}{|c|}{ ROE } & \multicolumn{4}{|c|}{$\mathrm{ROA}$} & \multicolumn{4}{|c|}{ GROWTH RANKING PRIOR 2 YEARS } \\
\hline & OLS & $\begin{array}{l}\text { Dynamic } \\
\text { OLS }\end{array}$ & $\begin{array}{l}\text { Fixed- } \\
\text { Effects }\end{array}$ & $\begin{array}{l}\text { GMM- } \\
\text { SYS }\end{array}$ & OLS & $\begin{array}{l}\text { Dynamic } \\
\text { OLS }\end{array}$ & $\begin{array}{l}\text { Fixed- } \\
\text { Effects }\end{array}$ & $\begin{array}{l}\text { GMM- } \\
\text { SYS }\end{array}$ & OLS & $\begin{array}{l}\text { Dynamic } \\
\text { OLS }\end{array}$ & $\begin{array}{l}\text { Fixed- } \\
\text { Effects }\end{array}$ & GMM-SYS \\
\hline Model & (1) & $(2)$ & (3) & (4) & $(5)$ & (6) & $(7)$ & $(8)$ & $(9)$ & $(10)$ & $(11)$ & $(12)$ \\
\hline $\begin{array}{l}\text { OVERALL EMPLOYEE } \\
\text { SATISFACTION }\end{array}$ & $\begin{array}{c}0.055^{* * *} \\
(3.41)\end{array}$ & $\begin{array}{c}0.057 * * * \\
(3.36)\end{array}$ & $\begin{array}{c}0.086 * * * \\
(2.94)\end{array}$ & $\begin{array}{c}0.105^{* *} \\
(2.26)\end{array}$ & $\begin{array}{c}0.123^{* *} \\
(2.14)\end{array}$ & $\begin{array}{c}0.133 * * \\
(2.21)\end{array}$ & $\begin{array}{l}0.007 \\
(0.74)\end{array}$ & $\begin{array}{l}0.008 \\
(0.48)\end{array}$ & $\begin{array}{l}6.542 * \\
(1.64)\end{array}$ & $\begin{array}{l}8.039 * \\
(1.82)\end{array}$ & $\begin{array}{c}23.113 * * * \\
(3.48)\end{array}$ & $\begin{array}{c}28.009 * * \\
(2.26)\end{array}$ \\
\hline FIRM SIZE & $\begin{array}{c}-0.027 * * * \\
(-5.54)\end{array}$ & $\begin{array}{c}-0.026 * * * \\
(-5.12)\end{array}$ & $\begin{array}{c}-0.036 * * \\
(-2.25)\end{array}$ & $\begin{array}{c}-0.044 * * \\
(-2.51)\end{array}$ & $\begin{array}{c}-0.013 * * * \\
(-7.01)\end{array}$ & $\begin{array}{c}-0.013 * * * \\
(-6.75)\end{array}$ & $\begin{array}{c}-0.046^{* * *} \\
(-8.56)\end{array}$ & $\begin{array}{c}-0.029 * * * \\
(-4.21)\end{array}$ & $\begin{array}{l}0.248 \\
(0.23)\end{array}$ & $\begin{array}{l}-1.076 \\
(-0.90)\end{array}$ & $\begin{array}{c}10.575 * * * \\
(2.98)\end{array}$ & $\begin{array}{c}13.910 * * * \\
(5.22)\end{array}$ \\
\hline FINANCIAL_LEVERAGE & $\begin{array}{c}-0.075 * * * \\
(-3.41)\end{array}$ & $\begin{array}{c}-0.075 * * * \\
(-3.31)\end{array}$ & $\begin{array}{c}-0.079 * * * \\
(-4.81)\end{array}$ & $\begin{array}{c}-0.099 * * \\
(-2.12)\end{array}$ & $\begin{array}{l}0.001 \\
(0.11)\end{array}$ & $\begin{array}{l}0.002 \\
(0.43)\end{array}$ & $\begin{array}{c}-0.010 * * \\
(-2.00)\end{array}$ & $\begin{array}{l}0.001 \\
(0.06)\end{array}$ & $\begin{array}{l}-4.101 \\
(-1.36)\end{array}$ & $\begin{array}{l}-5.596 \\
(-1.61)\end{array}$ & $\begin{array}{l}-3.648 \\
(-0.97)\end{array}$ & $\begin{array}{l}-9.118 * \\
(-1.69)\end{array}$ \\
\hline BRAZILIAN CAPITAL & $\begin{array}{l}0.025 \\
(1.53)\end{array}$ & $\begin{array}{l}0.025 \\
(1.43)\end{array}$ & $\begin{array}{l}0.010 \\
(0.45)\end{array}$ & $\begin{array}{l}0.031 \\
(1.29)\end{array}$ & $\begin{array}{c}-0.012 * * \\
(-1.97)\end{array}$ & $\begin{array}{c}-0.013^{* *} \\
(2.04)\end{array}$ & $\begin{array}{c}-0.020 * * * \\
(-2.73)\end{array}$ & $\begin{array}{l}-0.014 \\
(-1.48)\end{array}$ & $\begin{array}{l}2.152 \\
(0.56)\end{array}$ & $\begin{array}{l}3.349 \\
(0.81)\end{array}$ & $\begin{array}{l}2.103 \\
(0.42)\end{array}$ & $\begin{array}{l}9.005 * \\
(1.95)\end{array}$ \\
\hline SOUTHEAST REGION & $\begin{array}{l}-0.026^{*} \\
(-1.80)\end{array}$ & $\begin{array}{l}-0.025 \\
(-1.56)\end{array}$ & $\begin{array}{l}-0.024 \\
(-1.09)\end{array}$ & $\begin{array}{l}-0.017 \\
(-0.74)\end{array}$ & $\begin{array}{l}0.001 \\
(0.01)\end{array}$ & $\begin{array}{l}0.001 \\
(0.04)\end{array}$ & $\begin{array}{l}-0.002 \\
(-0.25)\end{array}$ & $\begin{array}{c}0.09 \\
(1.12)\end{array}$ & $\begin{array}{l}-2.480 \\
(-0.66)\end{array}$ & $\begin{array}{l}-3.383 \\
(-0.77)\end{array}$ & $\begin{array}{l}-4.685 \\
(-0.96)\end{array}$ & $\begin{array}{l}-8.340 * \\
(-1.83)\end{array}$ \\
\hline $\begin{array}{l}\text { LAGGED_PERFORMANCE } \\
\left(\mathrm{ROE}_{\mathrm{t}-1} \text { or } \mathrm{ROA}_{\mathrm{t}-1}\right)\end{array}$ & & $\begin{array}{l}0.004 \\
(0.19)\end{array}$ & & $\begin{array}{c}0.095 * * \\
(2.02)\end{array}$ & & $\begin{array}{l}-0.021 \\
(-0.95)\end{array}$ & & $\begin{array}{l}0.045 \\
(1.00)\end{array}$ & & $\begin{array}{c}0.094 * \\
(1.97)\end{array}$ & & $\begin{array}{l}0.122 \\
(1.61)\end{array}$ \\
\hline INDUSTRY DUMMIES & YES & YES & NO & YES & YES & YES & $\mathrm{NO}$ & YES & YES & YES & $\mathrm{NO}$ & YES \\
\hline YEAR DUMMIES & YES & YES & YES & YES & YES & YES & YES & YES & YES & YES & YES & YES \\
\hline Constant & $\begin{array}{l}0.050 \\
(0.69)\end{array}$ & $\begin{array}{l}0.054 \\
(0.67)\end{array}$ & $\begin{array}{l}0.150 \\
(0.96)\end{array}$ & & $\begin{array}{c}0.116^{* * * *} \\
(4.34)\end{array}$ & $\begin{array}{c}0.118 * * * \\
(4.03)\end{array}$ & $\begin{array}{c}0.417 * * * \\
(7.85)\end{array}$ & & $\begin{array}{l}-26.531 \\
(-1.53)\end{array}$ & $\begin{array}{l}-4.985 \\
(-0.26)\end{array}$ & $\begin{array}{c}-147.81 * * * \\
(4.19)\end{array}$ & \\
\hline Number of observations & 2,117 & 1,893 & 2,117 & 1,526 & 2,193 & 2,024 & 2,193 & 1,608 & 2,060 & 1,573 & 2,060 & 1,573 \\
\hline
\end{tabular}


Table 2 (continued)

\begin{tabular}{|c|c|c|c|c|c|c|c|c|c|c|c|c|}
\hline \multirow{2}{*}{$\frac{\text { Dependent Variable }}{\text { Method }}$} & \multicolumn{4}{|c|}{ ROE } & \multicolumn{4}{|c|}{ ROA } & \multicolumn{4}{|c|}{ GROWTH RANKING PRIOR 2 YEARS } \\
\hline & OLS & $\begin{array}{c}\text { Dynamic } \\
\text { OLS }\end{array}$ & $\begin{array}{l}\text { Fixed- } \\
\text { Effects }\end{array}$ & $\begin{array}{l}\text { GMM- } \\
\text { SYS }\end{array}$ & OLS & $\begin{array}{l}\text { Dynamic } \\
\text { OLS }\end{array}$ & $\begin{array}{l}\text { Fixed- } \\
\text { Effects }\end{array}$ & $\begin{array}{l}\text { GMM- } \\
\text { SYS }\end{array}$ & OLS & $\begin{array}{c}\text { Dynamic } \\
\text { OLS }\end{array}$ & $\begin{array}{l}\text { Fixed- } \\
\text { Effects }\end{array}$ & GMM-SYS \\
\hline Number of groups & & & 808 & 601 & & & 816 & 612 & & & 752 & 586 \\
\hline Prob > F & 0.000 & 0.000 & 0.000 & 0.000 & 0.000 & 0.000 & 0.000 & 0.000 & 0.000 & 0.000 & 0.000 & 0.000 \\
\hline $\mathrm{AR}(2)$ test $\mathrm{p}$-value & & & & 0.045 & & & & 0.322 & & & & 0.027 \\
\hline Hansen test p-value & & & & 0.131 & & & & 0.085 & & & & 0.018 \\
\hline Diff-in-Hansen tests p-value & & & & 0.610 & & & & 0.117 & & & & 0.007 \\
\hline
\end{tabular}

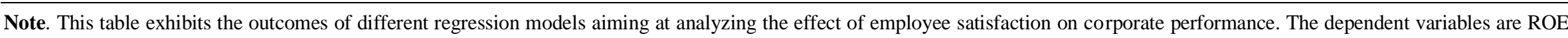

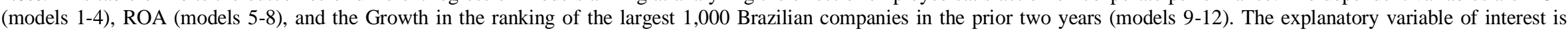

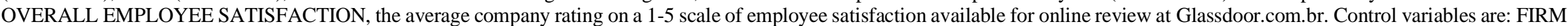

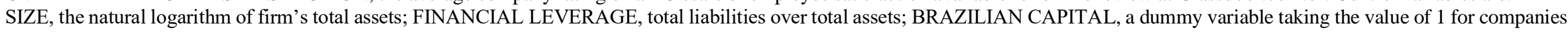

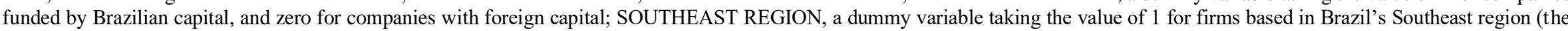

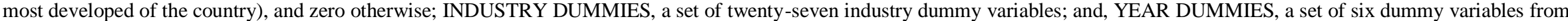

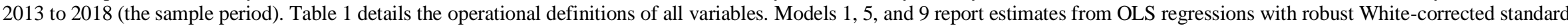

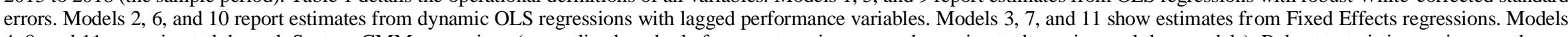

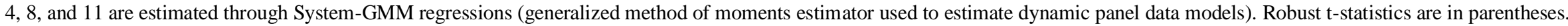
$* * *, * *$ and $*$ denote significance at the 1,5 , and $10 \%$ levels, respectively. 
The results for pooled OLS, dynamic OLS and fixed-effects models show that the average rating of employee satisfaction is positively associated with corporate performance measured by ROE, ROA, and Growth in ranking position (the only exception comes for ROA in the fixed-effects regression, in which case the coefficient is not statistically significant). The first column shows, for instance, that the coefficient of overall employee satisfaction on ROE is 0.055 and significant at the $1 \%$ level. This suggests that, ceteris paribus, a company moving from the $10^{\text {th }}$ percentile in terms of employee satisfaction (company rating $=2.70$ ) to the $90^{\text {th }}$ percentile (company rating $=3.86$ ) would be associated with an increase in ROE by $6.4 \%$ per year. If the company's ROE is equal to the sample's mean of $8.2 \%$, then a substantial increase of about $78 \%$ on its ROE would be expected. Alternatively, the coefficient suggests that a one-standard-deviation increase in company rating is associated with an increase in annual ROE by $2.7 \%$.

The more important results, though, come from the more robust System-GMM regressions. Here, the coefficients for overall employee satisfaction remain positive and significant for both ROE and Growth at the 5\% level. The exception once again comes from ROA, for which the coefficient is also positive but not statistically significant. In the case of ROE, for example, the Hansen test has a p-value of 0.131, while the difference-in-Hansen test $\mathrm{p}$-value is 0.610 . These tests suggest that it is not possible to reject the null hypothesis that the lagged instruments are valid. The coefficients of overall employee satisfaction for ROE also remain large $(0.105$, about double the size of the OLS coefficient), corroborating the idea of a relevant economic impact in the case of this performance indicator. On the other hand, it is worth mentioning that Hansen diagnostic for the performance variable Growth has rejected the null hypothesis of validity and exogeneity of instruments subset, avoiding causal inferences for this variable.

This result is in line in with the previous literature on this field using online reviews, particularly Huang et al. (2015), Symitsi, Stamolampros and Daskalakis (2018), Symitsi, Stamolampros, Daskalakis and Korfiatis (2018), and Chang et al. (2018), with no relevant contradictions to stand out. It is also important to note that these prior studies had a different focus. Huang et al. (2015), for instance, analyze the link between employee satisfaction and performance in family-owned firms, a specific type of ownership structure. Symitsi, Stamolampros and Daskalakis (2018) and Symitsi, Stamolampros, Daskalakis and Korfiatis (2018) focus on equity prices as a measure of performance. Chang et al. (2018), in turn, investigate the impacts of employee satisfaction by centering on the creation of shareholder value around mergers.

I also run regressions using the fours dimensions of employee satisfaction as explanatory variables of interest to investigate their effect on firm performance. Table 7 exhibits these results. 
Table 3

\section{The Effect of Different Dimensions of Employee Satisfaction on Company Performance}

\begin{tabular}{|c|c|c|c|c|c|c|c|c|c|c|c|c|}
\hline \multirow{2}{*}{$\frac{\text { Dependent Variable }}{\text { Method }}$} & \multicolumn{4}{|c|}{ ROE } & \multicolumn{4}{|c|}{ ROA } & \multicolumn{4}{|c|}{ GROWTH RANKING PRIOR 2 YEARS } \\
\hline & OLS & Dynamic OLS & Fixed-Effects & GMM-SYS & OLS & Dynamic OLS & Fixed-Effects & GMM-SYS & OLS & Dynamic OLS & Fixed-Effects & GMM-SYS \\
\hline Model & (13) & (14) & $(15)$ & (16) & (17) & (18) & (19) & $(20)$ & $(21)$ & $(22)$ & $(23)$ & (24) \\
\hline \multirow{2}{*}{ CULTURE } & $0.069 * * *$ & $0.064 * * *$ & $0.094 * * *$ & $0.104 * *$ & $0.019 * *$ & $0.020 * * *$ & 0.003 & 0.006 & 2.358 & -4.210 & -3.927 & -12.667 \\
\hline & $(3.37)$ & $(3.20)$ & $(2.85)$ & $(2.20)$ & $(2.54)$ & $(2.58)$ & $(0.26)$ & $(0.37)$ & $(0.41)$ & $(-0.69)$ & $(-0.53)$ & $(-1.06)$ \\
\hline \multirow{2}{*}{ COMPENSATION_\& BENEFITS } & -0.006 & -0.009 & $0.059^{*}$ & 0.036 & $-0.013 * *$ & $-0.013 * *$ & 0.017 & 0.007 & -5.647 & -3.233 & 4.356 & -5.412 \\
\hline & $(-0.34)$ & $(-0.55)$ & $(1.88)$ & $(0.92)$ & $(-2.24)$ & $(-1.97)$ & $(1.57)$ & $(0.49)$ & $(-1.28)$ & $(-0.64)$ & $(0.62)$ & $(-0.55)$ \\
\hline \multirow{2}{*}{ CAREER_OPPORTUNITIES } & 0.007 & 0.003 & 0.014 & 0.002 & $0.178 * * *$ & $0.172 * * *$ & 0.001 & 0.003 & $8.647 * *$ & $8.554 *$ & 8.711 & $23.680 * *$ \\
\hline & $(0.41)$ & $(0.19)$ & $(0.49)$ & $(0.04)$ & $(2.85)$ & $(2.65)$ & $(0.04)$ & $(0.23)$ & $(1.96)$ & $(1.71)$ & $(1.38)$ & $(2.29)$ \\
\hline \multirow{2}{*}{ WORK-LIFE BALANCE } & -0.023 & -0.010 & $-0.074 * *$ & -0.054 & $-0.013 *$ & $-0.014^{*}$ & -0.009 & -0.010 & 0.642 & 7.445 & $13.659 *$ & $22.597 * *$ \\
\hline & $(-1.18)$ & $(-0.51)$ & $(-2.31)$ & $(-1.23)$ & $(-1.87)$ & $(-1.86)$ & $(-0.82)$ & $(-0.64)$ & $(0.11)$ & $(1.22)$ & $(1.89)$ & $(1.96)$ \\
\hline \multirow{2}{*}{ FIRM SIZE } & $-0.027 * * *$ & $-0.026 * * *$ & $-0.038 * *$ & $-0.048 * * *$ & $-0.014 * * *$ & $-0.014 * * *$ & $-0.046 * * *$ & $-0.030 * * *$ & 0.218 & -0.875 & $10.795 * * *$ & $10.451 * *$ \\
\hline & $(-5.76)$ & $(-5.24)$ & $(-2.38)$ & $(-2.90)$ & $(-7.22)$ & $(-6.94)$ & $(-8.49)$ & $(-4.50)$ & $(0.20)$ & $(-0.74)$ & $(3.02)$ & $(2.27)$ \\
\hline \multirow{2}{*}{ FINANCIAL_LEVERAGE } & $-0.075 * * *$ & $-0.074 * * *$ & $-0.079 * * *$ & $-0.098 * *$ & 0.001 & 0.002 & $-0.010 * *$ & -0.001 & -4.14 & -5.450 & -3.678 & $-11.350 * *$ \\
\hline & $(-3.38)$ & $(-3.30)$ & $(-4.84)$ & $(-2.13)$ & $(0.11)$ & $(0.42)$ & $(-1.97)$ & $(-0.10)$ & $(-1.34)$ & $(-1.59)$ & $(-0.98)$ & $(-2.16)$ \\
\hline \multirow{2}{*}{ BRAZILIAN CAPITAL } & $0.030^{*}$ & $0.029 *$ & 0.012 & 0.038 & -0.010 & $-0.011 *$ & $-0.020 * * *$ & -0.014 & 2.458 & 3.000 & 1.919 & 6.348 \\
\hline & $(1.80)$ & $(1.65)$ & $(0.56)$ & $(1.58)$ & $(-1.62)$ & $(-1.69)$ & $(-2.69)$ & $(-1.44)$ & $(0.63)$ & $(0.72)$ & $(0.39)$ & (1.39) \\
\hline \multirow{2}{*}{ SOUTHEAST REGION } & $-0.026^{*}$ & -0.024 & -0.023 & -0.018 & 0.001 & 0.001 & -0.002 & 0.008 & -1.844 & -2.897 & -4.683 & -6.470 \\
\hline & $(-1.76)$ & $(-1.49)$ & $(-1.03)$ & $(-0.77)$ & $(0.25)$ & $(0.29)$ & $(-0.21)$ & $(1.03)$ & $(-0.49)$ & $(-0.67)$ & $(-0.96)$ & $(-1.49)$ \\
\hline \multirow{2}{*}{$\begin{array}{l}\text { LAGGED_PERFORMANCE }\left(\text { ROE }_{t-}\right. \\
\left.1 \text { or } \mathrm{ROA}_{\mathrm{t}-1}\right)\end{array}$} & & 0.005 & & $0.089 *$ & & -0.022 & & 0.051 & & $0.094 * *$ & & 0.122 \\
\hline & & $(0.22)$ & & $(1.89)$ & & $(-0.98)$ & & $(1.15)$ & & $(1.96)$ & & $(1.62)$ \\
\hline INDUSTRY DUMMIES & YES & YES & NO & YES & YES & YES & NO & YES & YES & YES & $\mathrm{NO}$ & YES \\
\hline
\end{tabular}


Table 7 (continued)

\begin{tabular}{|c|c|c|c|c|c|c|c|c|c|c|c|c|}
\hline \multirow{2}{*}{$\frac{\text { Dependent Variable }}{\text { Method }}$} & \multicolumn{4}{|c|}{ ROE } & \multicolumn{4}{|c|}{ ROA } & \multicolumn{4}{|c|}{ GROWTH RANKING PRIOR 2 YEARS } \\
\hline & OLS & Dynamic OLS & Fixed-Effects & GMM-SYS & OLS & Dynamic OLS & Fixed-Effects & GMM-SYS & OLS & Dynamic OLS & Fixed-Effects & GMM-SYS \\
\hline Model & (13) & (14) & (15) & (16) & (17) & $(18)$ & (19) & (20) & $(21)$ & $(22)$ & (23) & (24) \\
\hline YEAR DUMMIES & YES & YES & YES & YES & YES & YES & YES & YES & YES & YES & YES & YES \\
\hline \multirow{2}{*}{ Constant } & 0.824 & 0.852 & 0.132 & & $0.133 * * *$ & $0.135 * * *$ & $0.403 * * *$ & & -22.548 & -6.506 & $-146.71 * * *$ & -6.506 \\
\hline & $(1.13)$ & $(1.05)$ & $(0.81)$ & & $(4.90)$ & $(4.54)$ & $(7.27)$ & & $(-1.31)$ & $(-0.34)$ & $(-4.01)$ & $(-0.34)$ \\
\hline Number of observations & 2,117 & 1,893 & 2,117 & 1,526 & 2,193 & 2,024 & 2,193 & 1,608 & 2,060 & 1,573 & 2,060 & 1,573 \\
\hline Number of groups & & & 808 & 601 & & & 816 & 612 & & & 752 & 586 \\
\hline Prob $>\mathrm{F}$ & 0.000 & 0.000 & 0.000 & 0.000 & 0.000 & 0.000 & 0.000 & 0.000 & 0.000 & 0.000 & 0.000 & 0.000 \\
\hline Adjusted R-squared & 0.105 & 0.101 & 0.047 & & 0.104 & 0.105 & 0.021 & & 0.042 & 0.066 & 0.001 & 0.066 \\
\hline $\mathrm{AR}(1)$ test $\mathrm{p}$-value & & & & 0.000 & & & & 0.000 & & & & 0.000 \\
\hline $\mathrm{AR}(2)$ test $\mathrm{p}$-value & & & & 0.074 & & & & 0.300 & & & & 0.037 \\
\hline Hansen test $p$-value & & & & 0.202 & & & & 0.379 & & & & 0.022 \\
\hline Diff-in-Hansen tests p-value & & & & 0.485 & & & & 0.184 & & & & 0.218 \\
\hline
\end{tabular}

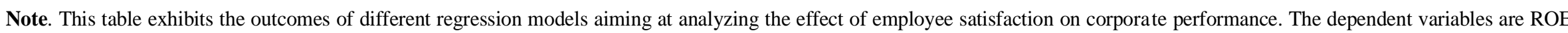

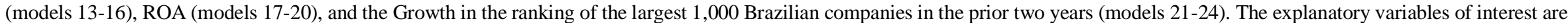

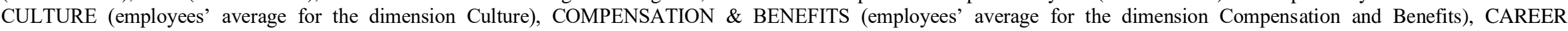

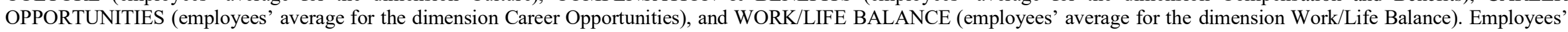

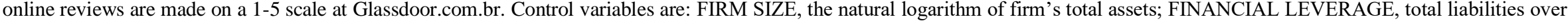

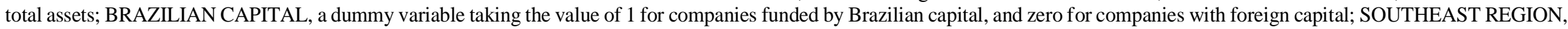

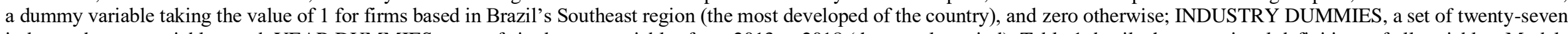

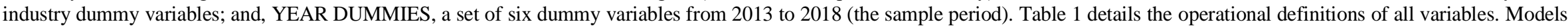

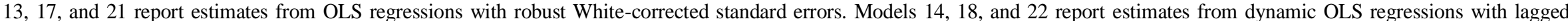

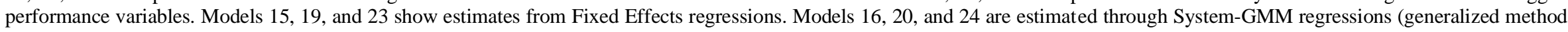
of moments estimator used to estimate dynamic panel data models). Robust t-statistics are in parentheses. ***, ** and * denote significance at the 1,5 , and $10 \%$ levels, respectively. 
As detailed in Table 3, the dimension on Culture is the most relevant in explaining improved corporate performance as proxied by ROE. In this case, the coefficients are positive and significant at least at the 5\% level in all econometric procedures, including the System-GMM regression. Its coefficients are also relevant. In the OLS estimate, for instance, a company moving from the $10^{\text {th }}$ percentile in terms of culture (rating $=2.59$ ) to the $90^{\text {th }}$ percentile (rating $=4.09$ ) would be associated with an increase in ROE by $10.4 \%$ per year, other things held constant. For a company with a ROE equal to the sample's mean of $8.2 \%$, this would mean a very large increase of about $127 \%$ on its ROE. It is important to note, though, that the coefficients for the culture dimension are not statistically significant in the GMM-Sys regressions for the two other performance variables.

Career opportunities is the other dimension showing a clear relationship with firm performance. For this variable, positive coefficients are observed in all regressions, although they are statistically significant in only about half of them. It is important to note that this variable exhibits a positive and significant coefficient at the 5\% level in the GMM-Sys regression using Growth in ranking position as the dependent variable (the same is true for the work-life balance dimension). On the other hand, the dimension on compensation \& benefits exhibited the more contradictory results with firm performance, with negative coefficients in almost half of them.

Taken together, these results indicate that, among the four dimensions of employee satisfaction, those related with intrinsic motivators such as culture and career opportunities are most positively associated with performance, while the dimension most closely related to extrinsic motivators (compensation \& benefits) is not associated with better performance.

\section{Robustness checks}

As discussed in the methodology section, the research model raises relevant endogeneity concerns such as reverse causality and omitted variables. In addition to resorting to different econometric procedures and making use of alternative operational definitions for firm performance, this section provides additional robustness checks.

I start by creating alternative variables for employee satisfaction. For overall satisfaction, I create two dummy variables named High employee satisfaction and Low employee satisfaction which correspond to the top and bottom quartiles of average company ratings, respectively. I then rerun all regressions using these variables in place of the original variable of overall employee satisfaction. Table 8 presents the results. 
Table 8

\section{Robustness Check I: The Effect of Different Dimensions of Employee Satisfaction on Company Performance}

\begin{tabular}{|c|c|c|c|c|c|c|c|c|c|c|c|c|}
\hline \multirow{2}{*}{$\frac{\text { Dependent Variable }}{\text { Method }}$} & \multicolumn{4}{|c|}{ ROE } & \multicolumn{4}{|c|}{ ROA } & \multicolumn{4}{|c|}{ GROWTH RANKING PRIOR 2 YEARS } \\
\hline & OLS & Dynamic OLS & Fixed-Effects & GMM-SYS & OLS & Dynamic OLS & Fixed-Effects & GMM-SYS & OLS & Dynamic OLS & Fixed-Effects & GMM-SYS \\
\hline Model & $(25)$ & (26) & $(27)$ & $(28)$ & (29) & $(30)$ & $(31)$ & $(32)$ & (33) & $(34)$ & $(35)$ & (36) \\
\hline HIGH_OVERALL_SATISFACTION & $\begin{array}{l}0.019 \\
(1.24)\end{array}$ & $\begin{array}{l}0.024 \\
(1.51)\end{array}$ & $\begin{array}{l}0.023 \\
(0.97)\end{array}$ & $\begin{array}{l}0.06^{* *} \\
(2.09)\end{array}$ & $\begin{array}{l}-0.002 \\
(-0.46)\end{array}$ & $\begin{array}{l}0.001 \\
(0.10)\end{array}$ & $\begin{array}{l}-0.007 \\
(-0.89)\end{array}$ & $\begin{array}{l}-0.005 \\
(-0.45)\end{array}$ & $\begin{array}{l}0.594 \\
(0.16)\end{array}$ & $\begin{array}{l}2.888 \\
(0.76)\end{array}$ & $\begin{array}{l}1.666 \\
(0.32)\end{array}$ & $\begin{array}{l}-1.932 \\
(-0.26)\end{array}$ \\
\hline LOW_OVERALL_SATISFACTION & $\begin{array}{c}-0.045^{* * *} \\
(-2.63)\end{array}$ & $\begin{array}{c}-0.040 * * \\
(-2.24)\end{array}$ & $\begin{array}{c}-0.044 * * \\
(-1.95)\end{array}$ & $\begin{array}{c}-0.073 * * \\
(-2.19)\end{array}$ & $\begin{array}{c}-0.019 * * * \\
(-3.29)\end{array}$ & $\begin{array}{c}-0.018 * * * \\
(-3.05)\end{array}$ & $\begin{array}{c}-0.023 * * * \\
(-2.96)\end{array}$ & $\begin{array}{c}-0.028 * * \\
(-2.46)\end{array}$ & $\begin{array}{l}-6.691 * \\
(-1.69)\end{array}$ & $\begin{array}{l}-6.766 \\
(-1.55)\end{array}$ & $\begin{array}{c}-17.710 * * * \\
(-3.39)\end{array}$ & $\begin{array}{c}-29.85 * * * \\
(-3.07)\end{array}$ \\
\hline FIRM SIZE & YES & YES & YES & YES & YES & YES & YES & YES & YES & YES & YES & YES \\
\hline FINANCIAL_LEVERAGE & YES & YES & YES & YES & YES & YES & YES & YES & YES & YES & YES & YES \\
\hline BRAZILIAN CAPITAL & YES & YES & YES & YES & YES & YES & YES & YES & YES & YES & YES & YES \\
\hline SOUTHEAST REGION & YES & YES & YES & YES & YES & YES & YES & YES & YES & YES & YES & YES \\
\hline LAGGED_PERFORMANCE & NO & YES & NO & YES & NO & YES & NO & YES & NO & YES & NO & YES \\
\hline INDUSTRY DUMMIES & YES & YES & NO & YES & YES & YES & NO & YES & YES & YES & NO & YES \\
\hline YEAR DUMMIES & YES & YES & YES & YES & YES & YES & YES & YES & YES & YES & YES & YES \\
\hline Constant & YES & YES & YES & YES & YES & YES & YES & YES & YES & YES & YES & YES \\
\hline Number of observations & 2,117 & 1,893 & 2,117 & 1,526 & 2,193 & 2,024 & 2,193 & 1,608 & 2,060 & 2,024 & 2,060 & 1,573 \\
\hline Number of groups & & & 808 & 613 & & & 816 & 612 & & & 752 & 586 \\
\hline Prob $>F$ & 0.000 & 0.000 & 0.000 & 0.000 & 0.000 & 0.000 & 0.000 & 0.000 & 0.000 & 0.000 & 0.000 & 0.000 \\
\hline Adjusted R-squared & 0.102 & 0.098 & 0.049 & & 0.106 & 0.105 & 0.024 & & 0.039 & 0.105 & 0.015 & \\
\hline $\mathrm{AR}(1)$ test $\mathrm{p}$-value & & & & 0.000 & & & & 0.000 & & & & 0.000 \\
\hline $\operatorname{AR}(2)$ test $p$-value & & & & 0.194 & & & & 0.161 & & & & 0.019 \\
\hline Hansen test p-value & & & & 0.435 & & & & 0.160 & & & & 0.028 \\
\hline Diff-in-Hansen tests p-value & & & & 0.763 & & & & 0.277 & & & & 0.023 \\
\hline
\end{tabular}

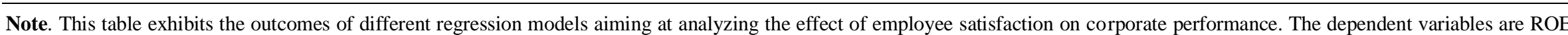

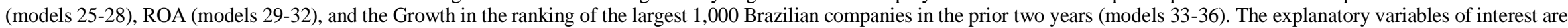

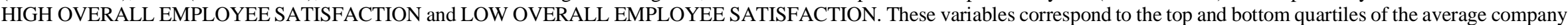

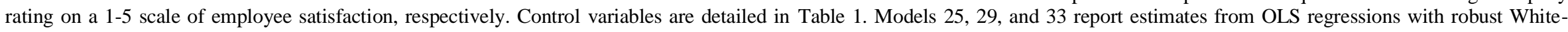

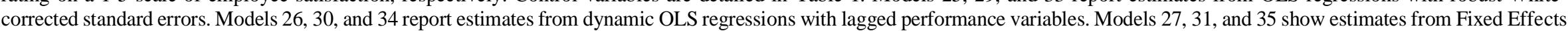

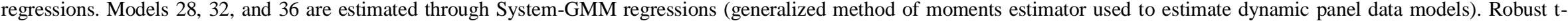
statistics are in parentheses. $* * *, * *$ and $*$ denote significance at the 1,5 , and $10 \%$ levels, respectively. 
The results presented in Table 8 can be viewed as complementary to the previous regressions. In all specifications, including GMM-Sys regressions, companies from the lower quartile in terms of overall employee satisfaction are associated with worst performance. On the other hand, though, the coefficient of the high satisfaction variable is positive and significant only for ROE in the GMM-Sys regression. The results suggest, therefore, that workplaces characterized by low levels of employee satisfaction destroy firm value, while the opposite is not necessarily true in the case of companies that positively stand out in terms of employee satisfaction.

I repeated the same procedure for each of the four dimensions on employee satisfaction (the table is omitted for space reasons and is available upon request). In this case, once gain the dimension on Culture is the most strongly one related to firm performance as companies from the top quartile in culture exhibit a superior ROE. Moreover, companies from the bottom quartile lose more positions in the ranking of 1,000 largest Brazilian firms compared to two years before. For the other dimensions, the coefficients of the dummy variables associated with the lower quartiles on employee satisfaction are significantly negative in virtually all specifications, while the coefficients of the variables related to higher satisfaction are not significant. The conclusion, therefore, is the same as for the variable on overall employee satisfaction: companies from the bottom quartile in terms of culture, compensation $\&$ benefits, career opportunities, and work/life balance destroy value, while those at the top quartiles on these issues do not necessarily outperform others.

In addition to this set of regressions, I also conducted the following robustness checks whose results, omitted due to space reasons, are available upon request. First, instead of restricting the analysis to companies with a minimum of 5 employee reviews per year, I run regressions using 3,10,20, and 50 as alternative minimums of employee reviews per year. Second, I rerun all tests using only reviews posted from current employees so that the results could not be driven by disgruntled former employees. And, third, I run all regressions using Ebitda as a performance variable and Recommendation of the company to others as an alternative measure of employee satisfaction. In cases, the results remained qualitatively the same.

\section{Conclusion}

I provide evidence of a positive and economically significant link between firm value and employee satisfaction in an emerging economy using online reviews posted at a local subsidiary of Glassdoor. The results are obtained after controlling for firm characteristics, industry, and time fixed-effects in System-GMM regressions and hold after robustness checks. This general conclusion is consistent with the findings of a burgeoning literature on this field that use a similar data source to measure employee satisfaction, such as Huang et al. (2015), Ji et al. (2017), Symitsi, Stamolampros and Daskalakis (2018), Symitsi, Stamolampros, Daskalakis and Korfiatis (2018), and Chang et al. (2018).

I also find interesting nuances in the employee satisfaction-firm performance relationship. Among the four dimensions of workers' well-being, those related to intrinsic motivators such as culture and career opportunities have shown to be more relevant for superior performance than extrinsic ones represented by compensation and benefits. In addition, the results suggest that companies with dissatisfied workers are more likely to suffer from poor performance than those with high satisfied employees are likely to produce superior performance.

To my knowledge, this is the first paper to investigate the link between firm value and employee satisfaction in a developing country based on online reviews as a measure of employee satisfaction. In particular, because my analysis covers a very turbulent economic period in Brazil in which the country suffered its greatest recession in history, the results suggest that employee satisfaction may be a particularly significant source of competitive advantage for companies in times of economic distress. In addition, this paper also contributes to the literature on human capital and intangibles in general by exploring the likely asymmetrical impact of employee satisfaction on performance.

Nonetheless, my results should be interpreted with caution because of important limitations. Above all, the research model and the limited amount of public information about the sample companies raise relevant 
endogeneity concerns such as reverse causality and the influence of omitted variables. Although I endeavor best efforts from the methodological standpoint to address such concerns, it is not possible to rule out that some results may be driven by spurious correlation, nor claim causality running from employee satisfaction to better firm performance.

This research has implications for academics and investors. For academics, my analysis provides further evidence supporting theories based on a human capital-centered view of the firm in which employees are viewed as key organizational elements for firm value and sustainability. It also provides support to self-determination theory and its emphasis on intrinsic motivators. For investors, this research reinforces the business case that employee welfare should be explicitly accounted for in ESG assessments and that employees' online reviews are of significant value relevance for capital allocation decisions.

\section{Note}

${ }^{1}$ Until June 26 ${ }^{\text {th }}$, 2019, Brazil's subsidiary of Glassdoor was called Love Mondays in Brazil (www.lovemondays.com.br). Love Mondays has been acquired by Glassdoor and, since this date, its name was changed accordingly to match its parent company (the website www.glassdoor.com.br replaced the former one).

\section{References}

Barnard, C. I. (1938). The functions of the executive. Cambridge, MA: Harvard University Press.

Chang, S. J., Oh, J. Y., \& Park, K. (2018). Employee satisfaction, career concerns, and acquirer performance [Working Paper Series No. 2016-013]. KAIST College of Business, Seoul, South Korea. Retrieved from https://ssrn.com/abstract=2827397

Edmans, A. (2011). Does the stock market fully value intangibles: Evidence from employee satisfaction and equity prices. Journal of Financial Economics, 101(3), 621-640. https://doi.org/10.1016/j.jfineco.2011.03.021

Edmans, A. (2012). The link between job satisfaction and firm value, with implications for corporate social responsibility. Academy of Management Perspectives, 26(4), 1-19. https://doi.org/10.5465/amp.2012.0046

Edmans, A., Li, L., \& Zhang, C. (2014). Employee satisfaction, labor market flexibility, and stock returns around the world [NBER Working Paper No. 20300]. National Bureau of Economic Research, Cambridge, MA. Retrieved from https://www.nber.org/papers/w20300

Filbeck, G., \& Preece, D. (2003). Fortune's best 100 companies to work for in America: Do they work for shareholders? Journal of Business Finance \& Accounting, 30(5-6), 771-797. https://doi.org/10.1111/14685957.05362

Follett, M. P. (1924). Creative experience. New York, NY: Longmans, Green and Co.

Grennan, J. (2013). A corporate culture channel: How increased shareholder governance reduces firm value. Retrieved from https://ssrn.com/abstract $=2345384$

Guiso, L., Sapienza, P., \& Zingales, L. (2015). The value of corporate culture. Journal of Financial Economics, 117(1), 60-76. https://doi.org/10.1016/j.jfineco.2014.05.010

Herzberg, F. (1959). The motivation to work. New York, NY: Wiley. 
Huang, M., Li, P., Meschke, F., \& Guthrie, J. P. (2015). Family firms, employee satisfaction, and corporate performance. Journal of Corporate Finance, 34, 108-127. https://doi.org/10.1016/j.jcorpfin.2015.08.002

Jensen, M. C., \& Meckling, W. H. (1976). Theory of the firm: Managerial behavior, agency costs and ownership structure. Journal of Financial Economics, 3(4), 305-360. https://doi.org/10.1016/0304-405x(76)90026-x

Ji, Y., Rozenbaum, O., \& Welch, K. T. (2017). Corporate culture and financial reporting risk: Looking through the glassdoor. Retrieved from https://ssrn.com/abstract=2945745

Maslow, A. H. (1943). A theory of human motivation. Psychological Review, 50(4), 370-396. https://psycnet.apa.org/doi/10.1037/h0054346

Mayo, E. (1933). The human problems of an industrial civilization. New York, NY: Macmillan Co.

McGregor, D. (1960). The human side of enterprise. New York, NY: McGraw-Hill.

Ryan, R. M., \& Deci, E. L. (2000). Self-determination theory and the facilitation of intrinsic motivation, social development, and well-being. American Psychologist, 55(1), 68-78. https://doi.org/10.1037//0003066x.55.1.68

Smith, A. (2007). An inquiry into the nature and causes of the wealth of nations (S. M. Soares, ed.). Retrieved from http://metalibri.wikidot.com/title:an-inquiry-into-the-nature-and-causes-of-the-wealth-of

Symitsi, E., Stamolampros, P., \& Daskalakis, G. (2018). Employees' online reviews and equity prices. Economics Letters, 162, 53-55. https://doi.org/10.1016/j.econlet.2017.10.027

Symitsi, E., Stamolampros, P., Daskalakis, G., \& Korfiatis, N. (2018). Employee satisfaction and corporate performance in the UK. Retrieved from https://ssrn.com/abstract=3140512

Taylor, F. W. (1911). The principles of scientific management. New York, NY: Harper \& Brothers.

Taylor, F. W. (1914). Scientific management. The Sociological Review, 7(3), 266-269. https://doi.org/10.1111/j.1467-954X.1914.tb02387.x

\section{Author}

Alexandre Di Miceli da Silveira

Av. Liberdade, 532, 01502-001, São Paulo, SP, Brasil

E-mail address: alexandre.miceli@fecap.br

(1) https://orcid.org/ 0000-0002-4864-9429

\section{Funding}

The author reported that there is no financial support for the research in this article.

\section{Conflict of Interest}

The author has stated that there is no conflict of interest.

\section{Plagiarism Check}

The RAC maintains the practice of submitting all documents approved for publication to the plagiarism check, using specific tools, e.g.: iThenticate.

\section{Supplementary Material}

The author says the compilation of the unique database for this study involved substantial personal investments from him. Also, its organization and standardization was extremely time-consuming. For these reasons, he opted to not make it publiclyavailable. In any case, he will be pleased to make available further analyses upon requests from readers as well as to clarify any doubts on the results. 